\title{
28 Research Square \\ Reverse Regulation Between sFRP 5 and Dkk 1 Gene in Early Stage Lung Adenocancer
}

Arife Zeybek ( $\square$ arifezeybek@mu.edu.tr )

Muğla Sıtkı Koçman Üniversitesi: Mugla Sitki Kocman Universitesi

Necdet $\mathrm{Oz}$

Private MedStar Hospital,Antalya /TURKEY

Serdar Kalemci

Private Medical Park Hospital ,Gebze/Kocaeli TURKEY

Kursad Tosun

Siena College

Tuba Gökdoğan Edgünlü

Mugla Sitki Kocman University, Medical Faculty,Medical Biology Deparment

Mehmet Tuğhan Kızıltuğ

Mersin University, Medical faculty,

\section{Leyla Tekin}

Mugla Sitki Kocman University Faculty of Science: Mugla Sitki Kocman Universitesi Fen Fakultesi

Mehmet Emin Erdal

Mersin University,Medical faculty

\section{Research Article}

Keywords: Dkk-1 gene, Dkk-3 gene, APC 1 gene, APC 3 gene, sFRP proteins, Lung adenocarcinogenesis

Posted Date: May 10th, 2021

DOI: https://doi.org/10.21203/rs.3.rs-434159/v1

License: (c) (i) This work is licensed under a Creative Commons Attribution 4.0 International License.

Read Full License 


\section{Abstract}

Purpose: We aimed to examine the expression levels of the genes of APC (Adenomatous Polyposis Coli) 1, APC 2, Dkk (Dickkopf related protein) 1, Dkk -3, sFRP (Secreted frizzled-related protein) -2, sFRP-4, and SFRP-5 genes which play a role in the Wnt signaling pathway in lung adenocarcinoma and adjacent normal lung tissues, and to evaluate their relationship with clinical-pathological factors.

Materials and methods: Between 2011 and 2018, the expression levels of the relevant genes in formalinfixed paraffin-embedded tumor and adjacent intact lung tissue samples of 57 patients who were operated for lung adenocarcinoma were determined by Real-time PCR analysis.

Results: The expression levels of the Dkk-1 gene in the tumor tissue, especially in stage I-II, were statistically significantly suppressed compared to normal tissue $(p<0.025)$. Although Dkk-1 gene expression was suppressed in the tumor tissue of patients with early-stage lung adenocarcinoma, the level of expression of the sFRP- 5 gene was found to be statistically significantly higher $(p<0.039)$.

Conclusion: In our study, between the sFRP-5 and Dkk-1 genes, known as the extracellular antagonist of the Wnt signaling pathway was found the reverse regulation. SFRP-5 gene was found as having an oncogenic role in adenocarcinoma development. Reverse regulation between these genes in early-stage lung adenocarcinoma may shed light on the mechanisms associated with the development of carcinogenesis. For that reason, clinically, this relationship needs to research in a larger series of pure adenocarcinoma and normal human lung tissues, separated by its stage, for potential therapeutic target or prognostic its significance.

\section{Highlights}

* Reverse regulation of DKK-1 and SFRP-5 gene in lung tissues with adenocarcinoma

* Reverse regulation of two extracellular Wnt signaling antagonists in early-stage lung adenocarcinoma

* Oncogenic role of the SFRP-5 gene in lung adenocarcinoma

* This reverse regulation may shed light on lung adenocarcinoma development mechanisms

* Potential therapeutic target or prognostic significance of this reverse regulation

\section{Introduction}

Lung cancers are one of the most important causes of cancer-related deaths. Mortality rates are high due to the fact that most of the patients with lung cancer are detected at an advanced stage and the prognosis is poor. Despite the early diagnosis, curative surgery, and oncological treatments, the recurrence rate is still high in early-stage tumors [1]. Cancer stem cells (CSC) are reported to be responsible for recurrence, resistance to chemo-radiotherapy, and metastasis [3]. 
Like somatic stem cells, CSCs are managed by Notch, Hedgehog, Wnt /-catenin, Ras-Raf [2-4]. Among these, the Wnt signaling pathway is still not clearly understood. The Wnt / $\beta$-catenin signaling pathway provides the transcription of myc, survivin, fibronectin, livin, Oct-4, Axin, Nanog, Snail, etc. proteins that play an important role in proliferation, cell cycle, and differentiation. The other 2 pathways other than the Wnt / $\beta$-catenin signaling pathway are called "signal pathways independent of $\beta$-catenin". These pathways have been associated with differentiation, cell polarity, and migration [5-9].

Studies on diseases caused by changes in the Wnt signaling pathway and the molecules involved in this pathway are widely available in the literature. The Wnt signaling pathway plays an important role in the occurrence of many diseases such as colorectal cancer (CRC), schizophrenia, retinal angiogenesis defect, Alzheimer's, tetra amelia, polycystic kidney diseases, leukemia, lung cancer, and osteoporosis, with a different mechanism disorder in each tissue [10-17]. The role of APC genes in Wnt signaling in carcinogenesis has been most prominently described for colorectal cancer, but abnormal Wnt signaling is observed in the presence of many more cancers $[13,15,16]$.

The aim of this study is to examine the expression of APC1, APC2, Dkk1, Dkk3, sFRP2, sFRP4, and sFRP5 transcripts in lung adenocarcinoma tissues and their corresponding normal lung tissues and to evaluate their relationship with clinico-pathological factors. We also aimed to help presenting new information about the role of the Wnt signaling pathway in lung adenocarcinoma development and progression.

\section{Materials And Methods}

Patients and Tissue Samples: The study was performed on 57 patients operated for lung adenocarcinoma between 2011-2018 in the thoracic surgery clinic. Our institutional Ethics Committee approved the study. The 7-8 $\mathrm{mm}$ sections were taken by the pathologist from the samples of tumoral and intact lung tissue embedded in formalin-fixed paraffin samples were centrifuged with xylene, to purify from paraffin, and the supernatant was discharged. After this process was repeated 2-3 times, pure ethanol was added and centrifuged to remove xylene. The supernatant was discharged, and the sample piece was left to dry for 10-15 minutes. $10 \%$ SDS, proteinase $\mathrm{K}$, and proteinase $\mathrm{K}$ buffer were added onto the tissue piece and incubated at $55^{\circ} \mathrm{C}$ for 3-3.5 hours.

RNA Extraction: In the next process, using the "RNA extraction with triazole" method, total RNA was obtained [18]. The purity and quantitation determinations of the obtained RNAs were made with a nanodrop spectrophotometer.

Reverse Transcriptase Polymerase Chain Reactions (RT-PCR): For cDNA synthesis; for reversetranscriptase polymerase chain reaction (RT-PCR), a mixture of Poly (T) 18 primers (table 1), 5xRT buffer, 2 mM dNTP, $200 \mathrm{U} / \mu \mathrm{L}$ RevertAid Reverse Transcriptase, $40 \mathrm{U} / \mu \mathrm{L}$ RiboLock RNase Inhibitor and distilled water for a total of $45 \mu \mathrm{l}$ has been prepared. $5 \mu \mathrm{l}$ of the total RNA sample obtained because of RNA isolation was added to the mixture. Under PCR conditions for 30 minutes at $16^{\circ} \mathrm{C}, 30$ minutes at $42^{\circ} \mathrm{C}$, and 5 minutes at $85^{\circ} \mathrm{C}$, the mRNAs were totally converted into CDNA and the samples were stored at -20 ${ }^{\circ} \mathrm{C}$ [19]. The expression levels of the relevant transcripts were determined by the QuantitativeComparative CT $(\triangle \Delta C T)$ method using a Real-Time PCR device (Applied Biosystems ${ }^{\mathrm{T}} 7500$ Real-Time 
PCR System). ACTB was chosen as the endogenous control. By placing $20 \mu \mathrm{l}$ of Master Mix, Forward and Reverse primers, specific probe, and distilled water mixtures into each well of the 96 -well plate, $5 \mu \mathrm{l}$ of CDNA was applied to the relevant mixtures. Real-time PCR analysis were performed for 2 minutes at $50^{\circ}$ $\mathrm{C}$ in the initial phase, 10 minutes at $95^{\circ} \mathrm{C}$, and 50 cycles at $95^{\circ} \mathrm{C}$ for 15 seconds, at $60^{\circ} \mathrm{C}$ for 90 seconds during the cycle phase. This procedure was repeated 3 times $[18,19]$.

\section{Statistical Analysis}

Paired t-test and Wilcoxon signed-rank tests were used to determine whether there was a statistically significant difference between the gene expressions of the tumor and adjacent normal lung tissues. Summary statistics are expressed as median and mean \pm standard deviation. For the relationship between clinical parameters, Fisher's Exact Test was used. In the analysis, $p$-value $<0.05$ was considered statistically significant. All analysis were made using the R statistical program.

\section{Construction and analysis of protein-protein interaction networks}

We used the String database (https://www.String-db.org) version 9.1 for functional, GO process, and KEGG pathway analysis.

\section{Results Of Study}

Fifty-seven patients who were operated with the diagnosis of lung adenocarcinoma between 2011 and 2018 were included in the study. Clinico-pathological characteristics of patients is presented in Supplemantary Table 1. The mean age of the patients was $63.18 \pm 8.28$ ( $\min =47$, $\max =77)$. Twentyfive $(56.1 \%)$ of these patients were below 65 years of age and $32(43.9 \%)$ were over 65 years old. The number of female patients was $22(38.6 \%)$ and the number of male patients was $35(61.4 \%)$. There were $33(58 \%)$ patients with right lung involvement and $24(42 \%)$ patients with left involvement. Clinical staging was done with PET-CT in the preoperative period. Lobectomy was performed in $47(82.5 \%)$ of the patients (Table 2). Minimum lymph node dissections at N2 $(n=3)$ and N1 $(n=3)$ levels were performed in the patients who underwent curative surgical treatment. Forty $(70.2 \%)$ of the patients were at stage I according to the pathology results (Table 3$)$. Histopathological, 28 (49.1\%) of the adenocarcinoma subtypes were of the mixed type (Table 4).

Again, in $8(14 \%)$ patients the tumor was well-differentiated, 49 (86\%) were moderately-poorly differentiated. Postoperative patients were followed up for an average of 43 (0-98) months. The average disease-free survival time was 39.4 months. Recurrence was detected in 14 (24.6\%) patients during follow-up. Eleven (19.3\%) patients died. A second primary tumor was detected in eight (14\%) patients during follow-up. The expression of APC1, APC2, Dkk-1, Dkk-3, sFRP-2, sFRP-4, sFRP-5 genes involved in the Wnt signaling pathway in paraffin-embedded tumors and adjacent normal lung tissues of patients were compared. 18 patients did not have normal lung tissues and 3 had against gene expression level was not included in the analysis. A statistically significant difference was found between the Dkk-1 gene expression levels of tumor tissue and neighboring normal lung tissue ( $\mathrm{p}$-value $=0.035$, Paired t-test) (Figure 1) (Table 5). 
In patients with stage I and II, a statistically significant difference was found between tumor tissue and adjacent normal lung tissue Dkk-1 gene expression levels. ( $p$-value $=0.011$, paired t-test) (Table 6) (Figure 2).

A statistically significant difference was found between the SFRP-5 gene expression levels of the tumor tissue and the adjacent normal lung tissue in patients with stage I and II (Table 7) (Figure 3). A statistically significant difference was found between tumor tissue and adjacent normal tissue SRFP-5 gene expression levels in patients without lymph node involvement (No) ( $p$-value $=0.011$, Wilcoxon signed-rank test) (Table 8) (Figure 4).

\section{Discussion}

The Wnt signaling pathway is modulated by extracellular and intracellular control mechanisms. Extracellular antagonists are Dkk, sFRP, Cerebrus, and WIF-1. Inside the cell, Dvl, APC, Axin, CK-1 a, GSK-3 $\beta$ Wnt play a role in the signal pathway. Especially sFRP and Dkk-1 genes are the most important extracellular antagonists. Dkk-1 and sFRP genes, which play a role in the Wnt pathway, have a tumorsuppressive role, and inhibit the Wnt signaling pathway [21]. Dkk-1 inhibits the canonical Wnt signaling pathway by binding to the Frizzled receptor and LRP 5/6. On the other hand, sFRP genes, bind directly to the Wnt ligand and show an antagonistic effect. SFRP genes inhibit both canonical and non-canonical signaling pathways [21]. The Wnt signaling pathway plays a key role in the development of lung adenocarcinoma [22,23]. In our study, expression levels of APC1, APC2, Dkk-1, Dkk-3, sFRP-2, sFRP-4, sFRP-5 genes involved in the Wnt signaling pathway were evaluated in paraffin-embedded lung adenocarcinoma and adjacent normal lung tissue. The expression levels of the Dkk-1 gene in tumor tissue, especially in stage I-II, were statistically significantly suppressed compared to normal tissue. Although Dkk-1 gene expression was suppressed in tumor tissue of patients with early-stage lung adenocarcinoma, the level of expression of SFRP - 5 gene, another extracellular antagonist, was found to be statistically significantly higher. This reverse regulation between Dkk-1 and SFRP -5 gene expressions was striking in our study. In the literature, cross-regulation between the sFRP-1 and Dkk-1 gene has also been associated with multidrug resistance [24].

Another remarkable result is that while the expression level of the Dkk-1 gene in tumor tissues is generally reported to be high in the literature, the opposite of the literature Dkk-1 gene expression was suppressed in our study. Studies of the Wnt signaling pathway in lung cancers have generally been studied in NSCLC cell cultures or adenocancer cell cultures, and studies in human tissues with homogeneous adenocarcinoma tumors are limited in the literature [25-28]. Differences in Dkk-1 gene expression levels have also been reported in NSCLC cell cultures [31]. Dkk-1 gene expression levels in NSCLC tissues of Xiao Yao et al. were in line with the results of our study and were suppressed [29]. Xiao Yao et al. pointed out that this difference in other studies may be ascribed to different sources of tissue samples [29]. The proportion of lung adenocarcinoma tissue is also higher in the authors' studies [29-31]. Our study was homogeneous and consisted of lung adenocarcinoma tissues and mostly stage I. As the stage progresses in lung cancers, the promoter methylation of the Dkk-1 gene increases advanced in other stages compared to the first stage. Overexpression of the Dkk-1 gene in advanced stages leads to 
increased cancer invasion and migration [37]. It fulfills this role through the PI3K / Akt signaling pathway $[14,37]$. For this, BAX and Bcl-2 signal with the AKT-1 pathway by inducing the increase of mRNA in apoptotic gene levels [37]. In our study, the protein-protein relationship of Dkk-1 and sFRP-5 was enriched with the String database [43] (Figure 5). These two proteins with dysregulation have agonistic and antagonistic roles in the Wnt signaling pathway in the GO process analyses [44] (Table 9). Dkk-1 protein is closely related to pro-oncogenes such as Wnt 3a, Wnt $8 b$, Wnt $8 a$, Wnt 1 as shown in figure 5 . The protein-protein relationship of the Dkk-1 and sFRP- 5 genes and the enriched analysis of the KEGG signaling pathway database also revealed their relationship with the mTOR, Hippo signaling pathway [45] (Table 10).

The role of the Dkk-1 gene in human cancer cells is still controversial. In mouse tumor models with advanced NSCLC and in vitro studies, blockade of Dkk-1 gene activity (DKN-01) reduced tumor proliferation and invasion [38]. Again, due to the role of the Dkk-1 gene in bone metabolism, it has been proposed as a biomarker in the early diagnosis of bone metastasis, where high expression levels play a role in bone metastasis in patients with lung cancer [14,30,32]. In our study, high expression levels of SFRP-5, one of the sFRP proteins, which is an extracellular antagonist of the Wnt ligand, were detected in early-stage adenocarcinoma tissues. The sFRP-5 gene is mostly involved in lipoprotein metabolism and plays a protective role in the development of cardiovascular disease $[39,40]$. There is no study on the relation with Wnt-mediated lung adenocarcinoma development and the sFRP - 5 gene in the PubMed database ("SFRP5 protein, human" [Supplementary Concept])AND "Adenocarcinoma of Lung"[Mesh]. Especially in the SFRP-5 gene and NSCLC cancer development, SFRP genes are prone to methylation, and methylation of the gene has been reported to be correlated with EGFR mutations. Patients with the methylated SFRP-5 gene have lower disease-free survival rates and higher EGFR_TKI drug resistance than other non-methylated patients [41]. Although sFRP genes are Wnt antagonists, biphasic effects on the Wnt signaling pathway have also been reported. Wnt agonistic effects of sFRP genes by increasing cJUN-terminal kinase activity through the non-canonical Wnt signaling pathway and inducing an increase in indirect Dkk-1 gene expression levels, increased Dkk gene expression levels in advanced stages have been tried to be explained in the literature [41].

On the other hand, studies by Liang et al. found that sFRP genes play an active role not only outside the cell but also inside the cell, bind B-catenin in the nucleus, and increase the expression of Wnt target genes, showing agonistic effects [42]. Contrary to what is known, the sFRP gene is not antagonistic, but an oncogenic role in the development of adenocarcinoma in the Wnt signaling pathway was also detected at an early stage in our study.

Also, in our study, as an explanation of difference or dysregulation between sFRP 5 and Dkk-1 gene expressions, it was reported that methylation and mRNA expression levels of sFRP 2 and Dkk-2 genes in gastric cancer tissues by Wang $\mathrm{H}$ et al. , methylation of these two genes were simultaneous, methylation rates were high, and the mRNA gene expression levels of the Dkk-2 gene were negatively correlated with the methylation rate. These authors argued that this signaling pathway and hypermethylation of genes were the underlying cause of gastric carcinogenesis [46]. 


\section{In Conclusion}

In our study that homogeneous that the expressions were comparing only of in human lung tumors with adenocarcinoma and normal lung tissues, in early-stage lung adenocarcinoma tissue the reverse regulating of the SFRP-5 and Dkk 1 genes known as the extracellular Wnt pathway antagonist were found. SFRP-5 gene was found as having an oncogenic role in early-stage lung adenocarcinoma development. Reverse regulation between these genes in early-stage lung adenocarcinoma may shed light on the mechanisms associated with the development of carcinogenesis. For that reason, clinically, this relationship needs to research in a larger series of pure adenocarcinoma and normal human lung tissues, separated by its stage, for potential therapeutic target or prognostic its significance.

\section{Symbols And Abbreviations Index}

sFRP: Secreted frizzled-related protein

Dkk: Dickkopf related protein

FZD: Frizzled receptor

GSK3ß: Glycogen synthase kinase 3 beta

LRP: Lipoprotein receptor-related protein

NSCLC: Non-small cell lung cancer

APC: Adenomatous Polyposis Coli

DVL: Disheveled related protein

CK1a: casein-kinase 1a protein

WIF: Wnt inhibitory factor

CSC: Cancer stem cell

EMT: Epithelial-to-mesenchymal transition

JNK: c-Jun N-terminal kinases protein

RYK: Receptor tyrosine kinase protein

ROS: Reactive oxygen species protein

ROR: Receptor tyrosine kinase-like orphan receptor

AXIN: axis inhibition protein 
TKI: Tyrosine Kinase Receptor Inhibitor

EGFR: Epidermal Growth Factor Releasing

BAX: BCL2 Associated X

Bcl-2: B-cell lymphoma

KEGG: Kyoto Encyclopedia of Genes and Genomes

\section{Declarations}

Ethics approval and consent participate

All procedures performed in studies involving human participants were in accordance with the ethical standards of the institutional and/or national research committee and with the 1964 Helsinki declaration and its later amendments or comparable ethical standards. Muğla Sıtkı Koçman University accepted the decision on 13.12.2018 and number 169 of the Ethics Committee of Human Investigations.

Declaration of competing interest

The authors declare that they have no known competing financial interests or personal relationships that could have appeared to influence the work reported in this paper.

Funding

This work was supported by the Mugla Sıtkı Koçman University with project number 19/087/07/3/4.

Author contribution

Zeybek A. project administration,investigation,write-original draft

Öz N. data curation, resources

Kalemci S. data curation, resources, English editing

Tosun K. formal analysis

Edgünlü G.T. writing,review editing

Kızıltuğ T.M. resources, analysis

Tekin L. resources

Erdal E.M. conceptualization,methodology, 


\section{References}

1. Parkin, D. M., Bray, F., Ferlay, J., \& Pisani, P. (2005). Global cancer statistics, 2002. CA: a cancer journal for clinicians, 55(2), 74-108. https://doi.org/10.3322/canjclin.55.2.74

2. Willert, K., Brown, J. D., Danenberg, E., Duncan, A. W., Weissman, I. L., Reya, T., Yates, J. R., 3rd, \& Nusse, R. (2003). Wnt proteins are lipid-modified and can act as stem cell growth factors. Nature, 423(6938), 448-452. https://doi.org/10.1038/nature01611

3. Alamgeer, M., Peacock, C. D., Matsui, W., Ganju, V., \& Watkins, D. N. (2013). Cancer stem cells in lung cancer: Evidence and controversies. Respirology (Carlton, Vic.), 18(5), 757-764. https://doi.org/10.1111/resp.12094.

4. García Campelo, M.R., Curbera, G.A., Gallego, G.A. et al. (2011). Stem cell and lung cancer development: blaming the Wnt, Hh and Notch signalling pathway. Clin Trans/ Oncol 13, 77-83 https://doi.org/10.1007/s12094-011-0622-0

5. Van Amerongen R, Nusse R. (2009).Towards an integrated view of Wht signaling in development. Development; 136:3205-14. doi: 10.1242/dev.033910

6. Nusse R, Varmus HE. (1992). Wnt genes. Cell;;69(7):1073-87. https://doi.org/10.1016/00928674(92)90630-U

7. Nusse, R. (2005). Wnt signaling in disease and in development. Cell Res 15, 28-32. https://doi.org/10.1038/sj.cr.7290260.

8. Willert K., Nusse R. (1998) Beta-catenin: a key mediator of Wnt signaling. Curr Opin Genet Dev;8(1):95-102.. https://doi.org/https://doi.org/10.1016/S0959-437X(98)80068-3

9. Michael T. Veeman, Jeffrey D. Axelrod, Randall T. Moon. (2003); A Second Canon: Functions and Mechanisms of $\beta$-Catenin-Independent Wnt Signaling. Developmental Cell, Volume 5, Issue 3 , September, 367-377

10. Mazieres J., He B., You L., Xu Z., Jablons DM. (2005). Wnt signaling in lung cancer.Cancer Lett.;222(1):1-10.

11. Duchartre Y., Kim Y.M., Kahn M. (2016). The Wnt signaling pathway in cancer. Crit Rev Oncol Hematol. March ;99:141-9.

12. Bonnet D., Dick J.E. (1997). Human acute myeloid leukemia is organized as a hierarchy that originates from a primitive hematopoietic cell. Nat Med . 3(7);730-7.

13. Brabletz T., Hlubek F., Spaderna S., Schmalhofer O., Hiendlmeyer E., Jung A., et al. (2005). Invasion and Metastasis in Colorectal Cancer: Epithelial-Mesenchymal Transition, Mesenchymal-Epithelial Transition, Stem Cells and $\beta$-Catenin. Cells Tissues Organs,179:56-65.

14. Jiangli L., Qian Z., Yuedong H., Xijie Y. (2018). Bone turnover markers and novel biomarkers in lung cancer bone metastases. Bıomarkers, vol. 23, no. 6, 518-526.

15. Mojtabanezhad Shariatpanahi A, Yassi M, Nouraie M, Sahebkar A, Varshoee Tabrizi F, Kerachian M.A. (2018). The importance of stool DNA methylation in colorectal cancer diagnosis: A meta-analysis. PLoS ONE.13(7): e0200735. 
16. Ramez N. E., Shamshad A., Thanh D., Heather A. L., et al. (2016). Expression Patterns of the Wnt Pathway Inhibitors Dickkopf3 and Secreted Frizzled-Related Proteins 1 and 4 in Endometrial Endometrioid Adenocarcinoma. Int J Gynecol Cancer.January. 26(1): 125-132.

17. Turkseven C.H., Buyukakilli B., Balli E., Yetkin D., Erdal M.E., Yilmaz S.G., et al. (2017). Effects of Huperzine-A on the Beta-amyloid accumulation in the brain and skeletal muscle cells of a rat model for Alzheimer's disease. Life Sci. Sep . 1;184:47-57.

18. Chomczynski P., Sacchi N. (2006). The single-step method of RNA isolation by acid guanidinium thiocyanate-phenol-chloroform extraction: twenty-something years on. Nature protocols. vol. 1 no. 2

19. Schmittgen T.D., Livak K.J. (2008). Analyzing real-time PCR data by the comparative CT method. Nature Protocols.; 3(6):1101-1108

20. R Core Team (2016). R: A language and environment for statistical computing. R Foundation for Statistical Computing, Vienna, Austria. http://www.R-project.org.

21. Kawano Y., Kypta R. (2003). Secreted antagonists of the Wnt signaling pathway. Journal of Cell Science.. (116); 2627-2634).

22. Li J., Huang K.L., Zhang T., Li H., Zhao J., Wang H. Pan-cancer methylation, and expression profiling of adenocarcinomas revealed epigenetic silencing in the WNT signaling pathway. Neoplasma. 2016; 63:208-214.)

23. Tammela T., Sanchez-Rivera F.J., Cetinbas N.M., Wu, K., Joshi, N. S., Helenius, K., et al. (2017). A Wntproducing niche drives proliferative potential and progression in lung adenocarcinoma. Nature, .545(7654), 355-359.

24. Li, Y., Ma, C., Shi, X., Wen, Z., Li, D., Sun, M., Ding, H. (2014). Effect of nitric oxide synthase on multiple drug resistance is related to Wnt signaling in non-small cell lung cancer. Oncology Reports. 32, 17031708.

25. Dong L.L., Qu L.Y., Chu L.Y., Zhang X.H., Liu Y.H. (2014). Serum level of DKK-1 and its prognostic potential in non-small cell lung cancer.Diagnostic Pathology, 9:52.

26. Zhang J., Zhang X., Zhao X., Jiang M., Gu M., Wang Z., et al. (2017). DKK1 promotes migration and invasion of non-small cell lung cancer via $\beta$-catenin signaling pathway. Tumor Biology July. 1-9

27. Chu T., Teng J., Jiang L., Zhong H., Han B. (2014). Lung cancer-derived Dickkopf1 is associated with bone metastasis and the mechanism involves the inhibition of osteoblast differentiation. Biochem Biophys Res Commun. 443(3):962-968.

28. Sheng S.L., Huang G., Yu B., Qin W.X. (2009). Clinical Significance and Prognostic Value of Serum Dickkopf-1 Concentrations in Patients with Lung Cancer.Clinical Chemistry 55:9 .1656-1664.

29. Yao X., Jiang H., Zhang C., Wang H., Yang L., Yu Y., et al. (2010). Dickkopf-1 autoantibody is a novel serological biomarker for non-small cell lung cancer, Biomarkers,.15:2, 128-134,

30. Yang J., Liu Y., Mai X., Lu S., Jin L., Tai X. (2019). STAT1-induced upregulation of LINC00467 promotes the proliferation migration of lung adenocarcinoma cells by epigenetically silencing DKK1 to activate the Wnt/b-catenin signaling pathway. Biochemical and Biophysical Research Communications $514.118 \mathrm{e} 126$ 
31. Xıang X.J., Lıu Y.W., Chen D.D., Yu S. (2015) Differential expression of Dickkopf-1 among non-small cell lung cancer cells molecular medıcıne reports 12: 1935-1940.

32. Zhang J., Zhang X., Zhao X., Jiang M.,Gu M., Wang Z., et al. (2017). DKK1 promotes migration and invasion of non-small cell lung cancer via $\beta$-catenin signaling pathway. Tumor Biology.

33. Zhou J., Zhuo S.R., Yang X.Q., Qin C.X., Wang Z.L., (2014) . Serum Dickkopf-1 expression level positively correlates with a poor prognosis in breast cancer, Diagn. Pathol. 9161.

34. Takahashi N., Fukushima T., Yorita K., Tanaka H., Chijiiwa K., Kataoka H.(2010). Dickkopf-1 is overexpressed in human pancreatic ductal adenocarcinoma cells and is involved in invasive growth. Int. J. Cancer: 126, 1611-1620.

35. Sato N., Yamabuki T., Takano A., Koinuma J., Aragaki M., Masuda K., et al. (2010). Wnt inhibitor Dickkopf-1 as a target for passive cancer immunotherapy. Cancer Res.Jul 1;70(13):5326-3

36. Lucia D’Amico, Sahil Mahajan, Aude-Hélène Capietto, Zhengfeng Yang, Ali Zamani, Biancamaria Ricci, et al. (2016). Dickkopf-related protein 1 (Dkk1) regulates the accumulation and function of myeloid-derived suppressor cells in cancer. J Exp Med. May 2; 213(5): 827-840.

37. Li S., Qin X., Guo X., Cui A., He Y., Wei S., et al. (2013). Dickkopf-1 is oncogenic and involved in invasive growth in non-small cell lung cancer. PLoS One.8:e84944

38. Jaclyn A. Wall, Samuel J. Klempner, Rebecca C. Arend .(2020) The anti-DKK1 antibody DKN-01 as an immunomodulatory combination partner for the treatment of cancer, Expert Opinion on Investigational Drugs. 29:7, 639-644,

39. Liu L.B., Chen X.D., Zhou X.Y., Zhu Q. (2018). The Wnt antagonist and secreted frizzled-related protein 5: implications on lipid metabolism, inflammation, and type 2 diabetes mellitus. Biosci Rep.38(4):BSR20180011

40. Heller R.S., Dichmann D.S., Jensen J., Miller C., Wong G., Madsen O.D., et al. (2002). Expression patterns of Wnts, Frizzleds, sFRPs, and misexpression in transgenic mice suggesting a role for Wnts in pancreas and foregut pattern formation. Dev Dyn. Nov; 225(3):260-70.

41. Zhu, J., Wang, Y., Duan, J., Bai H., Wang Z., Wei L., et al. (2012).DNA Methylation status of Wnt antagonist SFRP5 can predict the response to the EGFR-tyrosine kinase inhibitor therapy in nonsmall cell lung cancer. J Exp Clin Cancer Res 31, 80.

42. Liang C.J., Wang Z. W., Chang Y.W., Lee K.C., Lin W. H., Lee J. L. (2019). SFRPs Are Biphasic Modulators of Wnt-Signaling-Elicited Cancer Stem Cell Properties beyond Extracellular Control. August Cell Reports 28(6):1511-1525.e5

43. Szklarczyk D., Gable A.L., Lyon D., Junge A., Wyder S., Huerta-Cepas J, et al. (2019). STRING v11: protein-protein association networks with increased coverage, supporting functional discovery in genome-wide experimental data sets. Nucleic Acids Res. Jan; 47: D607-613

44. Mi H., Huang X., Muruganujan A., Tang H., Mills C., Kang D., et al. (2019). PANTHER version 14: more genomes, a new PANTHER GO-slim, and improvements in enrichment analysis tools. Nucleic Acids Res. Jan.47(D1): D419-D426 
45. Kanehisa M, Goto S. (2000)."KEGG: Kyoto Encyclopedia of Genes and Genomes". Nucleic Acids Res. 28 (1): 27-30.

46. Wang H., Duan L., Qi X.L., Meng L., Xu Y.S., Wu T., et al. (2017). Concurrent Hypermethylation of SFRP2 and DKK2 Activates the Wnt/ $\beta$-Catenin Pathway and Is Associated with Poor Prognosis in Patients with Gastric Cancer. Mol Cells. Jan 31; 40(1): 45-53

\section{Tables}

Table 1. Primer/probe sequences of ACTB, APC1, APC2, Dkk1, Dkk3, sFRP2, sFRP4, and sFRP5 genes to be analyzed by quantitative RT-PCR 


\begin{tabular}{|c|c|c|c|}
\hline $\begin{array}{l}\text { Gene } \\
\text { Name }\end{array}$ & $\begin{array}{l}\text { Gene } \\
\text { ID* }\end{array}$ & $\begin{array}{l}\text { NCBI Reference Sequence } \\
\text { Number** }\end{array}$ & Primer/probe sequence ${ }^{\star \star \star}$ \\
\hline \multirow[t]{3}{*}{ ACTB } & 60 & NM_001101.4 & F 5'-GGCACCCAGCACAATGAAG-3' \\
\hline & & & R 5'-GCCGATCCACACGGAGTACT-3' \\
\hline & & & $\begin{array}{l}\text { Pr 5'-TCAAGATCATTGCTCCTCCTGAGCGC- } \\
\text { BHQ-1-3' }\end{array}$ \\
\hline \multirow[t]{3}{*}{ APC1 } & 324 & NM_022662.2 & 5'-GAACCTGGAGGTACTTCATGTGAA-3' \\
\hline & & & 5'-GCAAATGTTTGGCCCACTAAA-3' \\
\hline & & & $\begin{array}{l}\text { 5'-FAM-AGCGCTTCGTTCAAACAGCAATCCA- } \\
\text { BHQ-1-3' }\end{array}$ \\
\hline \multirow[t]{3}{*}{ APC2 } & 10297 & XM_005259475.2 & 5'-CATCAGCGAGCGGATGTG-3' \\
\hline & & & 5'-GCAGTTCTCGATGCAGATGGA-3' \\
\hline & & & $\begin{array}{l}\text { 5'-FAM-CCTCGAACTCAAGCTGCTGCCGG- } \\
\text { BHQ-1-3' }\end{array}$ \\
\hline \multirow[t]{3}{*}{ Dkk1 } & 22943 & NM_012242.3 & F 5'-AATGTATCACACCAAAGGACAAGAAG-3' \\
\hline & & & R 5'-CCAGAAGTGTCTAGCACAACACAA-3' \\
\hline & & & $\begin{array}{l}\text { Pr 5'-FAM- } \\
\text { TTTGTCTCCGGTCATCAGACTGTGCC-BHQ-1- } \\
3^{\prime}\end{array}$ \\
\hline \multirow[t]{3}{*}{ Dkk3 } & 27122 & NM_015881.5 & 5'-GTGCAAGCCGACCTTCGT-3' \\
\hline & & & 5'-CTCCATGAAGCTGCCAACTTC-3' \\
\hline & & & $\begin{array}{l}\text { 5'-FAM-CCTGCTGCCCAGAGAGGTCCCC-BHQ- } \\
1-3^{\prime}\end{array}$ \\
\hline \multirow[t]{3}{*}{ sFRP2 } & 6423 & NM_003013.2 & F 5'-TGCTTGAGTGCGACCGTTT-3' \\
\hline & & & R 5'-CAGGAGGTGGTCGCTGCTA-3' \\
\hline & & & $\begin{array}{l}\text { Pr 5'-FAM-ACAACGACCTTTGCATCCCCCTCG- } \\
\text { BHQ-1-3' }\end{array}$ \\
\hline \multirow[t]{3}{*}{ sFRP4 } & 6424 & NM_003014.3 & 5'-GCCGTGCTGCGCTTCTT-3' \\
\hline & & & 5'-TGATAGGGTCGTGCAGGAACT-3' \\
\hline & & & $\begin{array}{l}\text { 5'-FAM-CCATGTACGCGCCCATTTGCAC-BHQ-1- } \\
3^{\prime}\end{array}$ \\
\hline \multirow[t]{3}{*}{ sFRP5 } & 6425 & NM_003015.3 & 5'-TGATTGGAGCCCAGAAAAAGA-3' \\
\hline & & & 5'-TGGTGTCCTTGCGCTTCAG-3' \\
\hline & & & $\begin{array}{l}\text { 5'-FAM-AAGCTGCTCAAGCCGGGCCC-BHQ-1- } \\
3^{\prime}\end{array}$ \\
\hline
\end{tabular}


* http://www.ncbi.nlm.nih.gov/gene

** http://www.ncbi.nlm.nih.gov/RefSeq/

Table 2: Operative methods

\begin{tabular}{|llll|}
\hline \multicolumn{1}{|c}{ Operations } & Number & Ratio (\%) & Totally ratio (\%) \\
\hline Lobectomy & 47 & 82.5 & 82.5 \\
\hline Segmentectomy & 3 & 5.3 & 87.7 \\
\hline Pneumonectomy & 3 & 5.3 & 93.0 \\
\hline Wedge Resection & 1 & 1.8 & 94.7 \\
\hline Bileobectomy & 3 & 5.3 & 100.0 \\
\hline Total & 57 & 100.0 & \\
\hline
\end{tabular}

Table 3: Distribution of cases according to pathological staging

\begin{tabular}{|llll|}
\hline \multicolumn{1}{|c}{ Stages } & Number & Ratio $(\%)$ & Totally ratio $(\%)$ \\
\hline Stage I & 40 & 70.2 & 70.2 \\
\hline Stage II & 7 & 12.3 & 82.5 \\
\hline Stage III & 9 & 15.8 & 98.2 \\
\hline Stage IV & 1 & 1.8 & 100.0 \\
\hline Total & 57 & 100.0 & \\
\hline
\end{tabular}

Table 4: Adenocarcinoma subtypes and rates 


\begin{tabular}{|llll|}
\hline \multicolumn{1}{|c}{ Subtype } & Number & Ratio (\%) & Total ratio \\
\hline Untyped & 12 & 21.1 & 21.1 \\
\hline Solid Type & 4 & 7.0 & 28.1 \\
\hline Acinar Type & 10 & 17.5 & 45.6 \\
\hline Mixt Type & 28 & 49.1 & 94.7 \\
\hline Lepidic Type & 1 & 1.8 & 96.5 \\
\hline Minimal invasive Type & 2 & 3.5 & 100.0 \\
\hline Total & 57 & 100.0 & \\
\hline
\end{tabular}

Table 5: Comparison of studied gene expression levels in tumor and normal tissue 


\begin{tabular}{|c|c|c|c|c|c|}
\hline Gene & Tissue & Sample number & Median & Mean \pm SD & P-value \\
\hline \multirow[t]{3}{*}{ APC1 } & Tumor & \multirow[t]{3}{*}{39} & 0.78 & $1.01 \pm 0.76$ & \multirow[t]{3}{*}{0.656} \\
\hline & Neighboring normal lung tissue & & 0.72 & $1.05 \pm 1.02$ & \\
\hline & Difference $=$ Tumor - Normal & & 0.02 & $-0.03 \pm 0.48$ & \\
\hline \multirow[t]{3}{*}{ APC2 } & Tumor & \multirow[t]{3}{*}{38} & 0.85 & $2.42 \pm 4.10$ & \multirow[t]{3}{*}{0.562} \\
\hline & Neighboring normal lung tissue & & 0.72 & $2.24 \pm 3.32$ & \\
\hline & Difference $=$ Tumor - Normal & & 0.02 & $0.19 \pm 1.98$ & \\
\hline \multirow[t]{3}{*}{ DKK-1 } & Tumor & \multirow[t]{3}{*}{27} & 1.19 & $3.18 \pm 3.96$ & \multirow[t]{3}{*}{0.035} \\
\hline & Neighboring normal lung tissue & & 3.50 & $5.55 \pm 6.14$ & \\
\hline & Difference $=$ Tumor - Normal & & -1.36 & $-2.37 \pm 5.51$ & \\
\hline \multirow[t]{3}{*}{ DKK-3 } & Tumor & \multirow[t]{3}{*}{33} & 0.65 & $1.15 \pm 1.11$ & \multirow[t]{3}{*}{0.459} \\
\hline & Neighboring normal lung tissue & & 0.64 & $1.20 \pm 1.28$ & \\
\hline & Difference $=$ Tumor - Normal & & 0.02 & $-0.05 \pm 0.38$ & \\
\hline \multirow[t]{3}{*}{ SFRP-2 } & Tumor & \multirow[t]{3}{*}{38} & 0.75 & $1.32 \pm 1.53$ & \multirow[t]{3}{*}{0.373} \\
\hline & Neighboring normal lung tissue & & 0.65 & $1.19 \pm 1.38$ & \\
\hline & Difference $=$ Tumor - Normal & & 0.08 & $0.13 \pm 0.86$ & \\
\hline \multirow[t]{3}{*}{ SFRP-4 } & Tumor & \multirow[t]{3}{*}{39} & 0.77 & $1.23 \pm 0.90$ & \multirow[t]{3}{*}{0.761} \\
\hline & Neighboring normal lung tissue & & 0.75 & $1.20 \pm 1.21$ & \\
\hline & Difference $=$ Tumor - Normal & & 0.07 & $0.04 \pm 0.71$ & \\
\hline \multirow[t]{3}{*}{ SFRP-5 } & Tumor & \multirow[t]{3}{*}{39} & 0.92 & $1.87 \pm 2.15$ & \multirow[t]{3}{*}{0.331} \\
\hline & Neighboring normal lung tissue & & 0.68 & $1.69 \pm 2.31$ & \\
\hline & Difference= Tumor - Normal & & 0.21 & $0.18 \pm 1.15$ & \\
\hline
\end{tabular}

Table 6: Comparison of tumor tissue and neighboring normal lung tissue DKK-1 gene expression levels in early-stage patients 


\begin{tabular}{|c|c|c|c|c|c|}
\hline Gene & Tissue & Sample number & Median & Mean \pm SD & P-value \\
\hline \multirow[t]{3}{*}{ DKK-1 } & Tumor & 23 & 1.066 & $2.547 \pm 3.288$ & 0.025 \\
\hline & Neighboring normal lung tissue & & 3.083 & $4.945 \pm 5.681$ & \\
\hline & Difference $=$ Tumor - Normal & & -1.060 & $-2.398 \pm 4.796$ & \\
\hline
\end{tabular}

Table 7: Comparison of SFRP-5 gene expression levels of tumor tissue and neighboring normal lung tissue in early-stage patients

\begin{tabular}{|c|c|c|c|c|c|}
\hline Gene & Tissue & Sample number & Median & Mean \pm SD & P-value \\
\hline \multirow[t]{3}{*}{ SFRP-5 } & Tumor & 34 & 0.919 & $1.516 \pm 1.635$ & 0.039 \\
\hline & Neighboring normal lung tissue & & 0.641 & $1.325 \pm 1.802$ & \\
\hline & Difference $=$ Tumor - Normal & & 0.219 & $0.191 \pm 0.751$ & \\
\hline
\end{tabular}

Table 8: Comparison of tumor tissue and neighboring normal tissue SRFP-5 gene expression levels in patients without nodal involvement (No)

\begin{tabular}{|c|c|c|c|c|c|}
\hline Gene & Tissue & Sample number & Median & Mean \pm SD & P-value \\
\hline \multirow[t]{3}{*}{ SFRP-5 } & Tumor & 28 & 0.919 & $1.471 \pm 1.686$ & 0.008 \\
\hline & Neighboring Normal Tissue & & 0.641 & $1.166 \pm 1.618$ & \\
\hline & Difference $=$ Tumor - Normal & & 0.298 & $0.305 \pm 0.614$ & \\
\hline
\end{tabular}

Table 9: Analyses table for GO-enriched biological process in which DKK-1 and SFRP-5 genes play a role 


\begin{tabular}{|c|c|c|c|}
\hline \multicolumn{4}{|c|}{ Biological Process (GO) } \\
\hline \multirow{2}{*}{$\begin{array}{l}\text { GO-term } \\
\text { GO:0016055 }\end{array}$} & \multirow{2}{*}{$\begin{array}{l}\text { Description } \\
\text { Wnt signaling pathway }\end{array}$} & \multicolumn{2}{|c|}{$\begin{array}{l}\text { count in gene set false discovery } \\
\text { rate }\end{array}$} \\
\hline & & 7 of 303 & $2.15 \mathrm{e}-10$ \\
\hline G0:0060828 & regulation of canonical Wnt signaling pathway & 6 of 218 & $3.35 e-09$ \\
\hline G0:0009952 & anterior/posterior pattern specification & 5 of 197 & $3.02 \mathrm{e}-07$ \\
\hline G0:0060070 & canonical Wnt signaling pathway & 4 of 93 & $2.26 c-06$ \\
\hline $\begin{array}{l}\text { GO: } \\
1904886\end{array}$ & beta-catenin destruction complex disassembly & 3 of 21 & $5.20 c-06$ \\
\hline G0:0090090 & $\begin{array}{l}\text { negative regulation of canonical Wnt signaling } \\
\text { pat. }\end{array}$ & 4 of 123 & $5.20 \mathrm{c}-06$ \\
\hline G0:0007369 & Gastrulation & 4 of 158 & $1.02 \mathrm{e}-05$ \\
\hline G0:0061317 & $\begin{array}{l}\text { canonical Wnt signaling pathway involved in } \\
\text { cardia }\end{array}$ & 2 of 2 & $3.78 e-05$ \\
\hline G0:0044335 & $\begin{array}{l}\text { canonical Wnt signaling pathway involved in } \\
\text { neural.. }\end{array}$ & 2 of 2 & $3.78 e-05$ \\
\hline G0:0001756 & Somitogenesis & 3 of 63 & $6.15 e-05$ \\
\hline G0:0090245 & axis elongation involved in somitogenesis & 2 of 4 & $7.56 c-05$ \\
\hline G0:0030279 & negative regulation of ossification & 3 of 71 & $7.87 e-05$ \\
\hline G0:0009966 & regulation of signal transduction & 7 of3033 & $9.06 c-05$ \\
\hline GO:0090244 & $\begin{array}{l}\text { Wnt signaling pathway involved in } \\
\text { somitogenesis }\end{array}$ & 2 of 5 & $9.20 c-05$ \\
\hline G0:0044332 & $\begin{array}{l}\text { Wnt signaling pathway involved in } \\
\text { dorsal/ventral a. }\end{array}$ & 2 of 5 & $9.20 \mathrm{e}-05$ \\
\hline GO:0060021 & roof of mouth development & 3 of 87 & 0.00010 \\
\hline GO:0009996 & negative regulation of cell fate specification & 2 of 6 & 0.00010 \\
\hline G0:0009953 & dorsal/ventral pattern formation & 3 of 87 & 0.00010 \\
\hline G0:0009798 & axis specification & 3 of 89 & 0.00010 \\
\hline G0:0090381 & regulation of heart induction & 2 of 7 & 0.00011 \\
\hline GO:0042661 & regulation of mesodermal cell fate specification & 2 of 7 & 0.00011 \\
\hline G0:0022411 & cellular component disassembly & 4 of 364 & 0.00011 \\
\hline G0:0009790 & embryo development & 5 of 890 & 0.00011 \\
\hline G0:0032526 & response to retinoic acid & 3 of 104 & 0.00012 \\
\hline
\end{tabular}




\begin{tabular}{|lllc|}
\hline G0:0051090 & $\begin{array}{l}\text { regulation of DNA-binding transcription factor } \\
\text { acti. }\end{array}$ & 4 of403 & 0.00013 \\
\hline G0:1904953 & $\begin{array}{l}\text { Wnt signaling pathway involved in midbrain } \\
\text { dopamin }\end{array}$ & 2 of 10 & 0.00015 \\
\hline G0:1904338 & $\begin{array}{l}\text { regulation of dopaminergic neuron } \\
\text { differentiation }\end{array}$ & 2 of 10 & 0.00015 \\
\hline G0:0014029 & neural crest formation & 6 of 1992 & 0.00015 \\
\hline G0:0030177 & positive regulation of Wnt signaling pathway & 3 of 126 & 0.00017 \\
\hline & & & 0.00018 \\
\hline
\end{tabular}

(number of nodes: 12)

(number of edges: 64)

(average node degree: 10.7)

(avg. local clustering coefficient: 0.973)

(expected number of edges: 11)

(PPI enrichment $p$-value:< $1.0 e-16)$

Table 10: Analyses of KEGG enriched signaling pathway in which DKK-1 and SFRP-5 genes play a role 


\begin{tabular}{|c|c|c|c|}
\hline & KEGG Pathways & & \\
\hline pathway & Description & $\begin{array}{l}\text { count in gene } \\
\text { set }\end{array}$ & $\begin{array}{l}\text { false discovery } \\
\text { rate }\end{array}$ \\
\hline hsa04310 & Wnt signaling pathway & 6 of 143 & $1.84 \mathrm{e}-11$ \\
\hline hsa05226 & Gastric cancer & 4 of 147 & $8.78 \mathrm{e}-07$ \\
\hline hsa05225 & Hepatocellular carcinoma & 4 of 163 & $8.78 \mathrm{e}-07$ \\
\hline hsa05224 & Breast cancer & 4 of 147 & $8.78 \mathrm{e}-07$ \\
\hline hsa04150 & mTOR signaling pathway & 4 of 148 & $8.78 \mathrm{e}-07$ \\
\hline hsa05200 & Pathways in cancer & 4 of 515 & $4.01 \mathrm{e}-05$ \\
\hline hsa05217 & Basal cell carcinoma & 2 of 63 & 0.00048 \\
\hline hsa04916 & Melanogenesis & 2 of 98 & 0.0010 \\
\hline hsa04550 & $\begin{array}{l}\text { Signaling pathways regulating pluripotency of } \\
\text { stem cells }\end{array}$ & 2 of 138 & 0.0017 \\
\hline hsa04934 & Cushing's syndrome & 2 of 153 & 0.0019 \\
\hline hsa04390 & Hippo signaling pathway & 2 of 152 & 0.0019 \\
\hline hsa05205 & Proteoglycans in cancer & 2 of 195 & 0.0026 \\
\hline hsa05166 & HTLV-I infection & 2 of 250 & 0.0038 \\
\hline hsa05165 & Human papillomavirus infection & 2 of 317 & 0.0056 \\
\hline
\end{tabular}

\section{Figures}




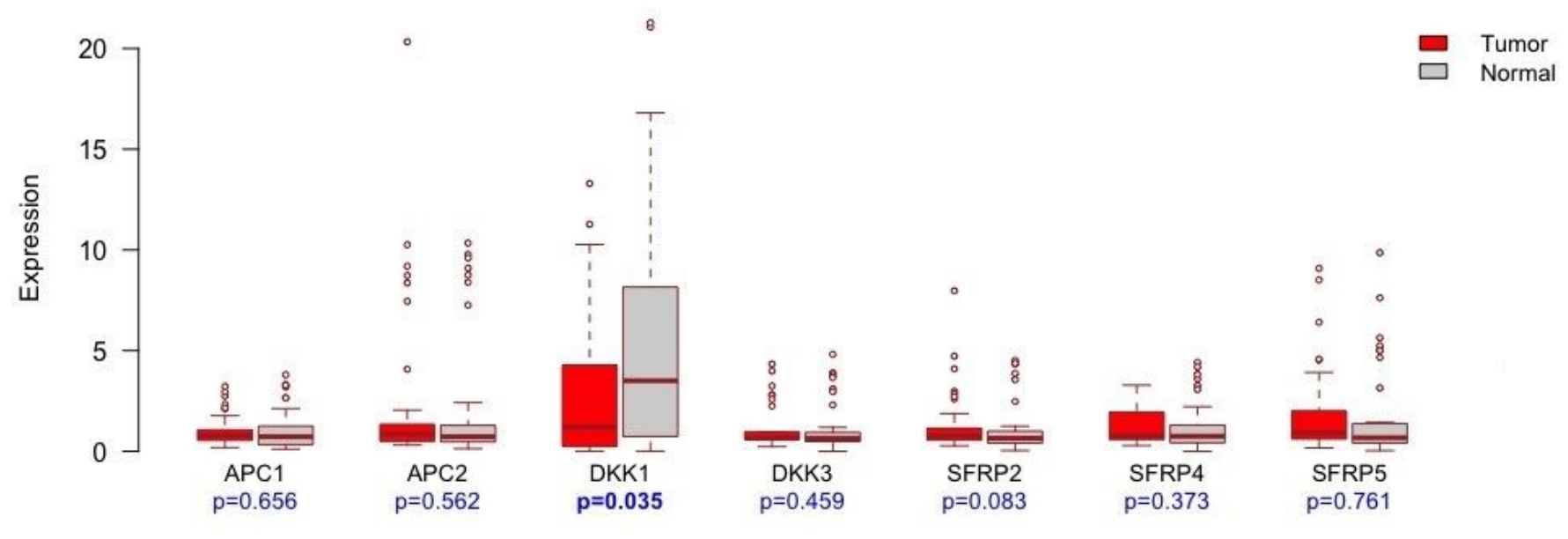

Figure 1

Graphical representation of the comparison of Wnt gene expression levels studied in lung adenocarcinoma and normal lung tissues.

\section{DKK1}

Stage I or II

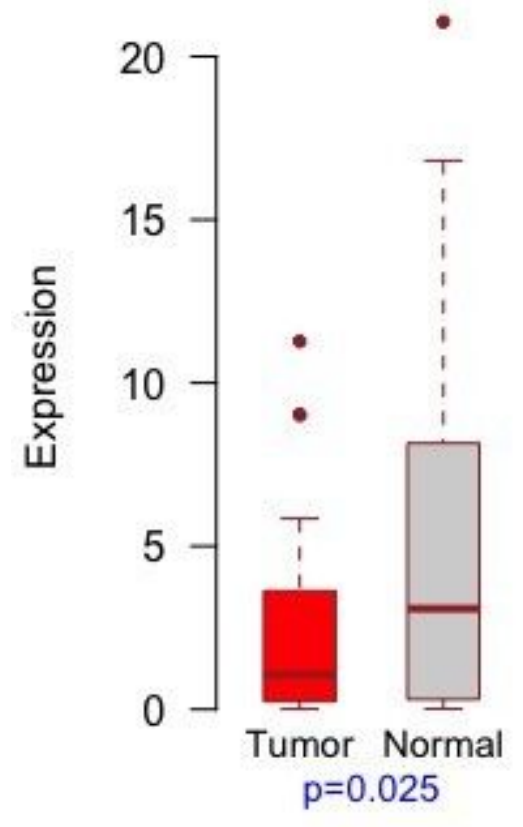

Figure 2 
Graphical representation of the comparison of Dkk-1 gene expression levels in early-stage lung adenocarcinoma and normal lung tissues.

\section{SFRP5 \\ Stage I or II}

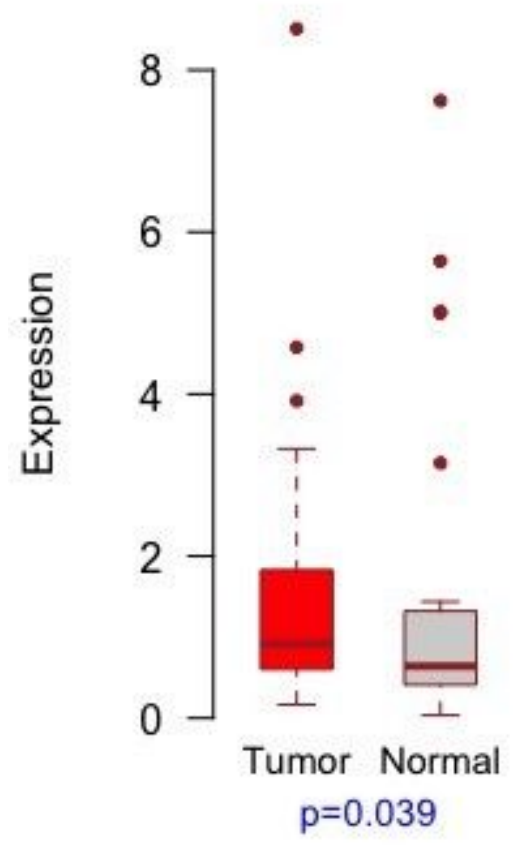

\section{Figure 3}

Graphical representation of the comparison of sFRP- 5 gene expression levels in early-stage lung adenocarcinoma and normal lung tissues. 


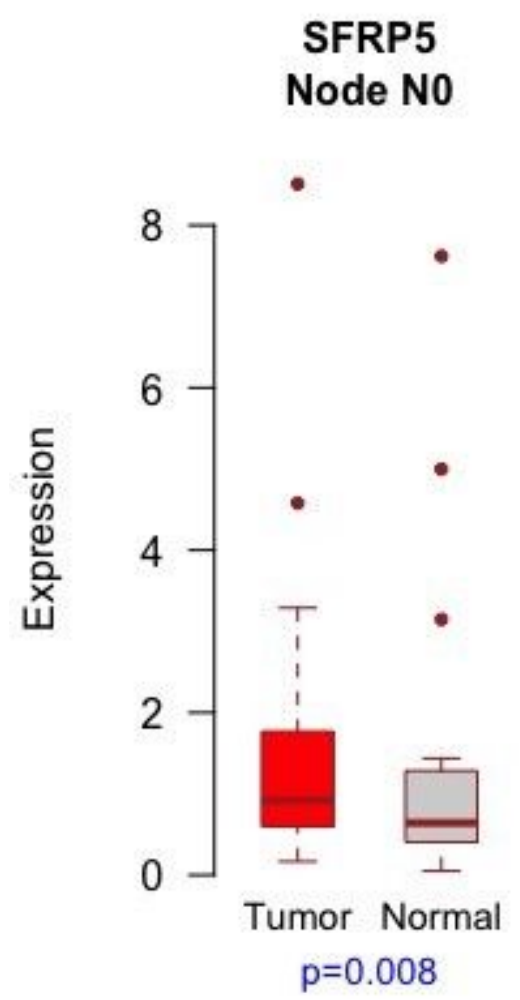

\section{Figure 4}

Graphical representation of the comparison of sRFP- 5 gene expression levels in early-stage lung adenocarcinoma and normal lung tissues with No. 


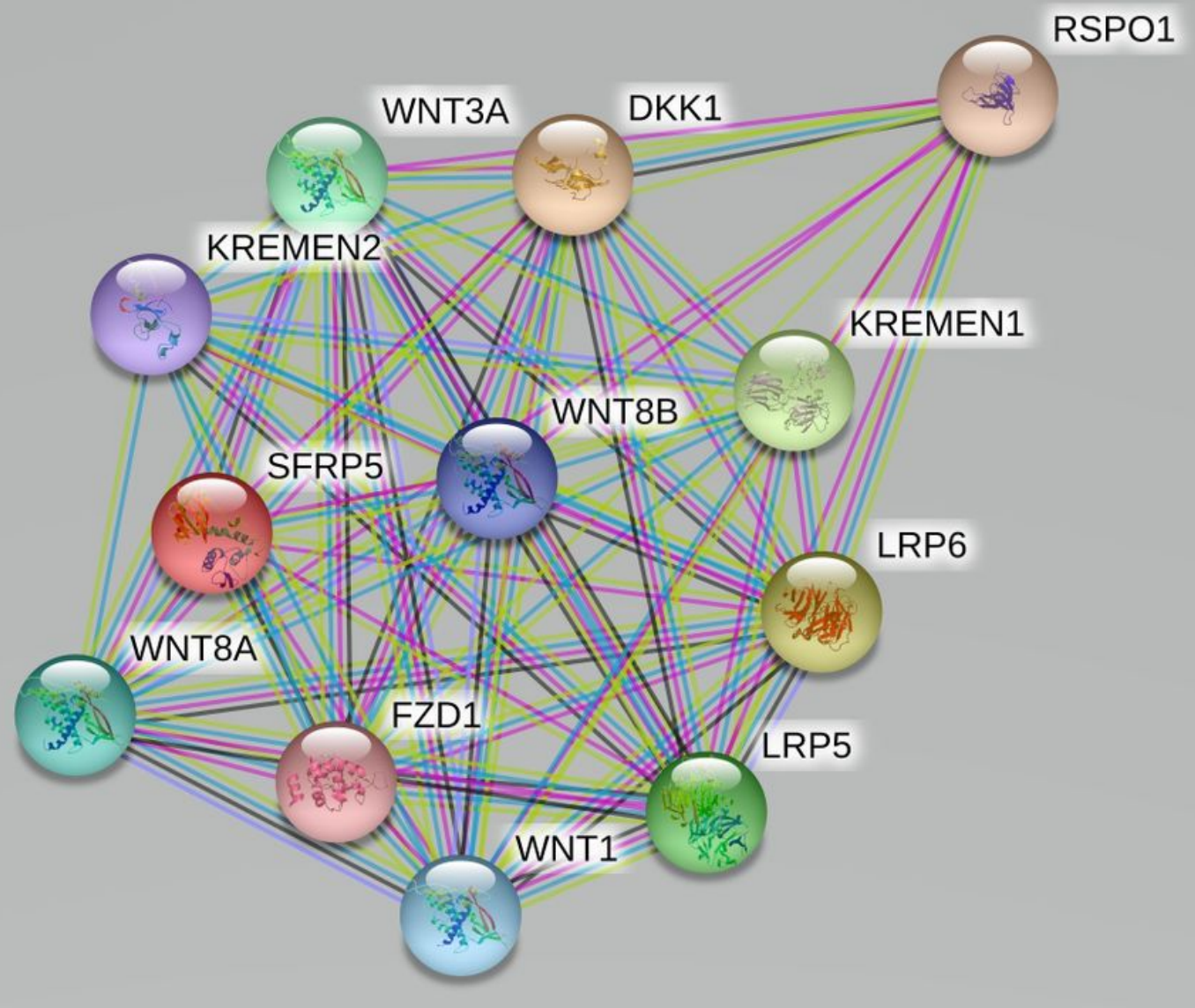

Figure 5

Protein-protein relationship of Dkk-1 and sFRP-5 genes enriched with String Database (43)

\section{Supplementary Files}

This is a list of supplementary files associated with this preprint. Click to download.

- supplementaryTable1.docx 